RUTMech, t. XXXIII, z. 88 (4/16), październik-grudzień 2016, s. 371-378

\author{
Lucjan WITEK ${ }^{1}$
}

\title{
EXPERIMENTAL MODAL ANALYSIS OF THE TURBINE BLADE
}

\begin{abstract}
In this paper the results of an experimental modal analysis of the turbine blade were presented. Investigations were made using the electrodynamic vibration system. As the results of analysis, the resonant frequencies of the blade were performed. The results of experimental investigations are dependent on many parameters of vibration system defined before the start of the test. In the first part of this study the influence of the frequency sweep rate on values of blade resonant frequency was investigated. In the next part of the work the effect of excitation intensity on value of the blade vibration amplitude was investigated. The stiffness of the grip used for fixation of the blade to the movable shaker head can have a large influence on the results of an experimental modal analysis. The fir tree slots of the blade were compressed in the grip using a special screw with fine thread. In the last part of the work the influence of the torque used for screw home on results of the modal analysis of the blade was examined. As the results of performed investigations the final conclusions were formulated.
\end{abstract}

Keywords: turbine blade, resonant vibrations, experimental analysis, sweep rate, intensity of excitation

\section{Introduction}

The turbine blades during the work of the engine are subjected to vibrations, excited by both the unbalanced rotor and the pulsation of pressure of the hot exhaust gases. The turbine blades have often a small cross-section area of the airfoil section (Fig. 1). The small bending stiffness causes that the resonant vibrations of the turbine can occur at relatively low frequencies. During the resonance, the large stress amplitude causes high-cycle fatigue of the blade material. The blade working in resonance conditions can be damaged in relatively short time [1-7].

The main objective of this work is the experimental determination of the resonant frequencies of the turbine blade. The additional goal of the study is

\footnotetext{
${ }^{1}$ Autor do korespondencji/corresponding author: Lucjan Witek, Rzeszow University of Technology, al. Powstańców Warszawy 12, 35-959 Rzeszów, Poland, e-mail: 1witek@prz.edu.pl
} 
the analysis of influence of selected parameters on the resonant frequency of the blade.

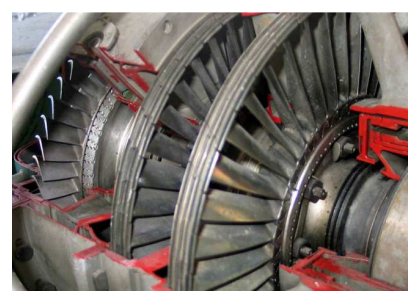

Fig. 1. View of the first and second stage turbine of an aero engine

\section{Object of investigations and the vibration system}

Investigated turbine blade is made out of EI-437-b nickel alloy. EI-437-b alloy has a good creep resistance and was used for rotational components of the turbine engines working at high temperature. The mass of investigated blade was equal to 40.4 grams. The experimental modal analysis of the turbine blade was made using the Unholtz-Dickie UDCO TA-250 vibration system (Figs. 2 and 3). The blade was horizontally mounted on the movable head of the shaker (Fig. 4). In the first test the frequency range of $400 \mathrm{~Hz}$ to $3600 \mathrm{~Hz}$ was defined.

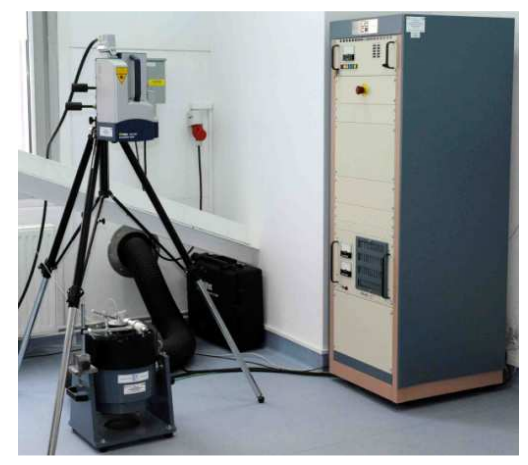

Fig. 2. Main components of the vibration system: shaker and amplifier (Unholtz-Dickie UDCO-TA-250)

In the next part of experimental investigations, the frequency was limited to the range of $800-1000 \mathrm{~Hz}$ in order to investigate the first mode of resonant vibrations only. In experimental investigations two measure channels were activated. The first channel was used to measure the amplitude of acceleration of the shaker head. The acceleration in this channel was measured by mediumsize (mass of 2 grams) piezoelectric sensor. The signal in the second channel was delivered from the small piezoelectric acceleration sensor. This sensor was located on the top of the blade airfoil section (Fig. 4). The small mass of the sensor ( 0.2 grams) causes that it has small influence on disturbances in dynamics of investigated object which mass is much higher (about 40 grams). 


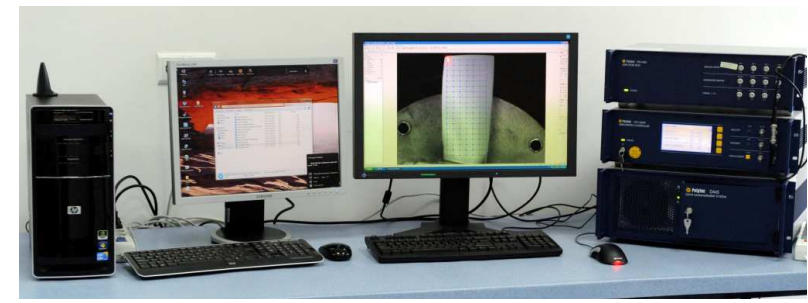

Fig. 3. View of the control panel used for both the definition of the preliminary settings of experimental test and also to visualization of the modal analysis results

Fig. 4. Investigated turbine blade fixed to the head of vibrator. On the airfoil section the small piezoelectric acceleration sensor is fixed to the blade

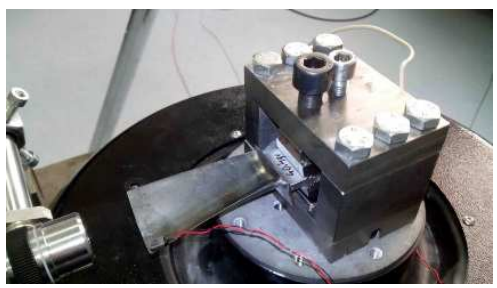

\section{Results of experimental modal analysis}

\subsection{Influence of sweep rate on resonant frequency of the blade}

The first modal test was performed at the following parameters: the frequency range of $400 \mathrm{~Hz}-3600 \mathrm{~Hz}$, the constant sweep rate of $1 \mathrm{~Hz} / \mathrm{s}$ and the constant intensity of excitation $3 \mathrm{~g}$ (where $1 \mathrm{~g}=9.81 \mathrm{~m} / \mathrm{s}^{2}$ ). The modal analysis was started from $400 \mathrm{~Hz}$. During the modal analysis the frequency of excitation was increased. At this time the signals from two measured channels were recorded. The main result of the modal analysis is the amplitude-frequency characteristic presented in Fig. 5. On the horizontal axis of the plot the actual frequency of excitation is defined. On the vertical axis the amplitude of vibration (measured on the top part of the blade) was defined.

The large peak, typical for resonance phenomenon occurs at $920.2 \mathrm{~Hz}$ (Fig. 5). This value is the resonant frequency $F_{\text {res }}$ (for the first mode of vibration). There is visible the second peak on the amplitude-frequency characteristic at $2393.6 \mathrm{~Hz}$. This value is the resonant frequency for the second mode of vibrations. The third measured resonant frequency equals $3385.8 \mathrm{~Hz}$ (Fig. 5).

Magnified amplitude-frequency characteristic of the blade is presented in Fig. 6. The frequency of excitation was limited to the range of $800-1000 \mathrm{~Hz}$. There is observed symmetric shape of the characteristic, typical for the blades without cracks [2]. The blade vibration amplitude (for mode I, intensity of excitation of $3 \mathrm{~g}$ and speed rate of $1 \mathrm{~Hz} / \mathrm{s}$ ) equals $0.27 \mathrm{~mm}$ (Fig. 6). 


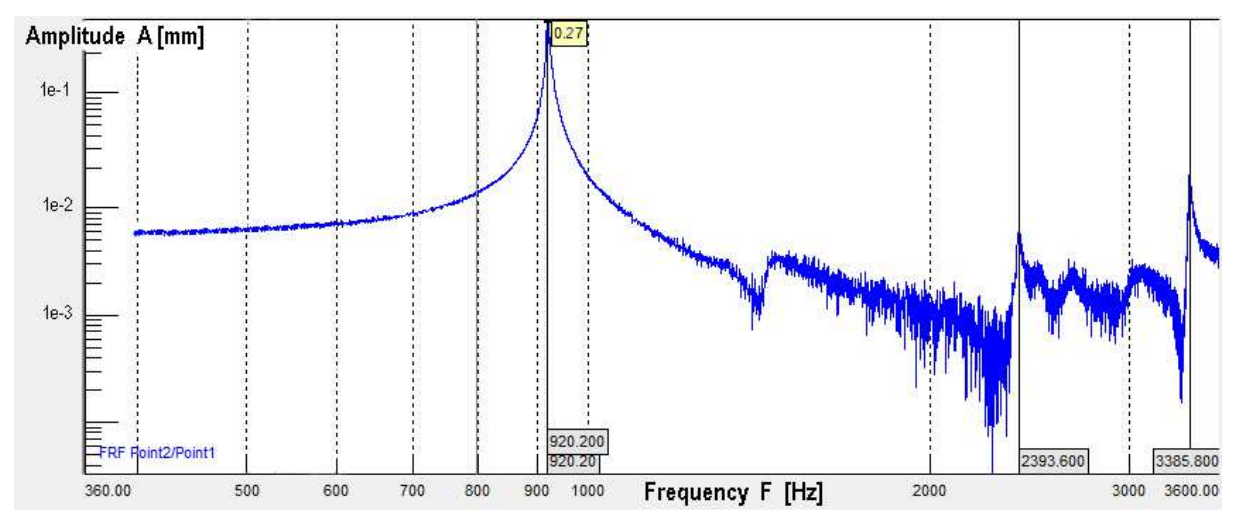

Fig. 5. Amplitude-frequency characteristic of the turbine blade (frequency range of 400-3600 $\mathrm{Hz}$, speed rate of $1 \mathrm{~Hz} / \mathrm{s}$, excitation intensity of $3 \mathrm{~g}$, screw torque of $15 \mathrm{Nm}$ ).

In this study the influence of selected parameters of experimental test on results of the modal analysis was investigated. The first considered parameter is the sweep rate. This parameter shows how fast the excitation frequency increases during the modal analysis. High value of the sweep rate causes that the results of an experimental modal analysis could be inaccurate.

In order to check the influence of sweep rate on values of the resonant frequency (mode I) the modal analysis was repeated for the different rates. The speed rate range of $0.5-64 \mathrm{~Hz} / \mathrm{s}$ was considered. The results of this study are presented in Fig. 7. As seen from this figure the constant resonant frequency $(920.2 \mathrm{~Hz})$ is observed for the sweep rate range of $0.5-2 \mathrm{~Hz} / \mathrm{s}$. At sweep rate values higher than $4 \mathrm{~Hz} / \mathrm{s}$ an increase of the resonant frequency is observed. For the speed rate of $64 \mathrm{~Hz} / \mathrm{s}$ the value of $\mathrm{F}_{\text {res }}$ is equal to $921.6 \mathrm{~Hz}$.

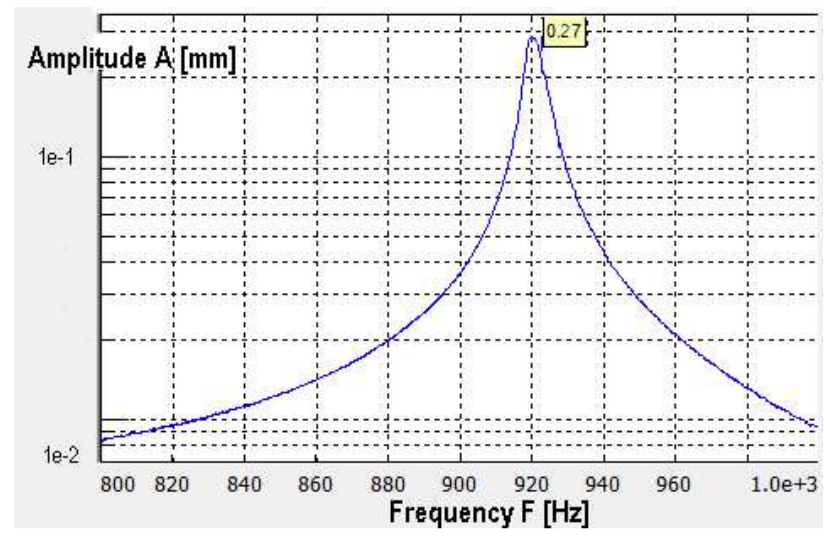

Fig. 6. Amplitude-frequency characteristic of the blade (frequency range of $800-1000 \mathrm{~Hz}$, speed rate of $1 \mathrm{~Hz} / \mathrm{s}$, excitation intensity of $3 \mathrm{~g}$, screw torque of $15 \mathrm{Nm}$ ) 


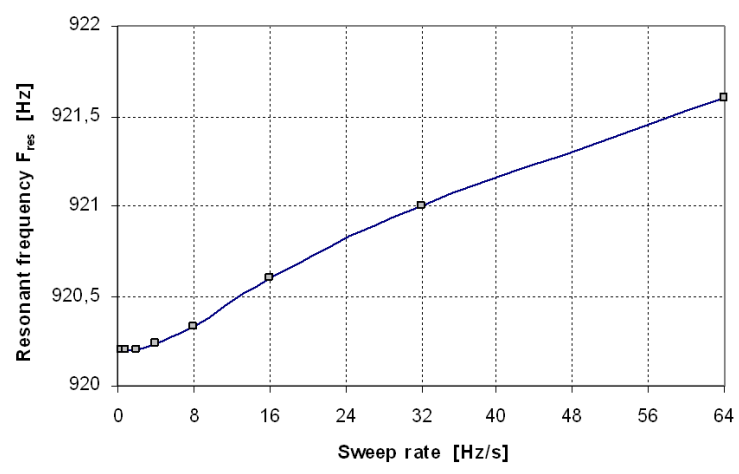

Fig. 7. Resonant frequency of the blade as a function of the sweep rate (excitation intensity of $3 \mathrm{~g}$, screw torque of $15 \mathrm{Nm}$ )

\subsection{Influence of excitation intensity on resonant frequency of the blade}

Results of an experimental modal analysis depend on many technical parameters which should be defined before the start of the test. One of the most important is the intensity of excitation. This intensity is defined in $[\mathrm{g}]$ units where $1 \mathrm{~g}=9.81 \mathrm{~m} / \mathrm{s}^{2}$. The modal analysis of the blade was made for the following intensity: $1 \mathrm{~g}, 3 \mathrm{~g}, 7 \mathrm{~g}, 15 \mathrm{~g}$ and $25 \mathrm{~g}$. The results presented in Fig. 8 showed that intensity of excitations has a large influence on resonant frequency obtained in experimental investigations. The resonant frequency (mode I) for the intensity of excitation of $1 \mathrm{~g}$ is equal to $921.4 \mathrm{~Hz}$. During increase of the intensity of excitation the resonant frequency decreases. For the highest considered intensity $(20 \mathrm{~g})$ the $\mathrm{F}_{\text {res }}$ has a value of $912.6 \mathrm{~Hz}$. The difference between mentioned results $(1 \mathrm{~g}$ and $20 \mathrm{~g}$ ) equals $8.8 \mathrm{~Hz}$. It means that the intensity of excitation has a larger influence on the resonant frequency than the sweep rate.

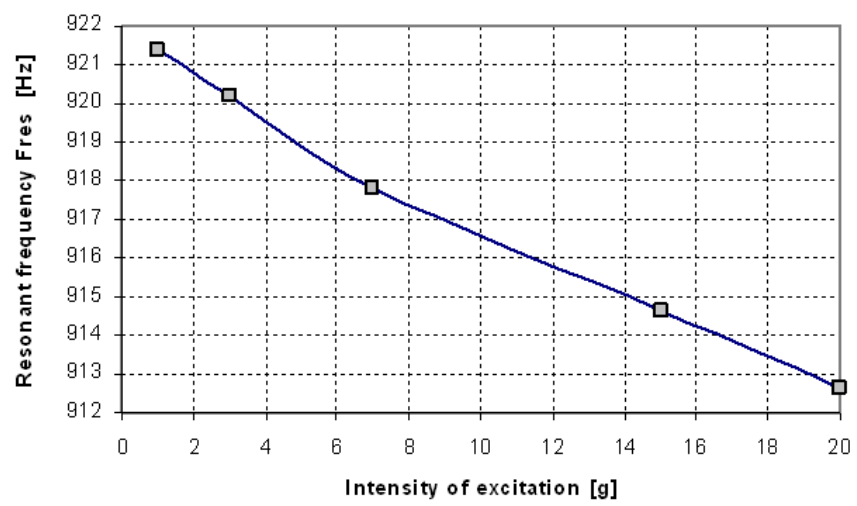

Fig. 8. Resonant frequency of the blade as a function of intensity of excitation (sweep rate $1 \mathrm{~Hz} / \mathrm{s}$, screw torque of $15 \mathrm{Nm}$ ) 


\subsection{Influence of screw torque on resonant frequency of the blade}

The blade was fixed to the movable head of the shaker with the use of the special grip made out of steel. The thick plates of the grip $(14 \mathrm{~mm})$ guarantee a high stiffness of its structure. The blade fir tree root was compressed into grip with the use of the screw with the fine thread (M10x1). The bottom part of the screw has a conical shape in order to assure the maximum value of the compression force at small screw torque. Both the screw thread and the screw conical surface were lubricated in order to minimize the torque. The screw torque was limited in investigations by small strength of the movable head of the shaker, which is suspended on the rubber connectors. The modal analysis of the blade was realized with the following screw torques: $7.5,10,12.5,15$ and $17 \mathrm{Nm}$.

The resonant frequency as a function of screw torque is presented in Fig. 9. There is visible that the resonant frequency strongly depends on the screw torque. For the torque of $7.5 \mathrm{Nm}$ the $\mathrm{F}_{\text {res }}$ equals about $882 \mathrm{~Hz}$. At the screw torque of $12.5 \mathrm{Nm}$ the measured resonant frequency has a value of $911 \mathrm{~Hz}$. The difference between two mentioned results $(7.5$ and $12.5 \mathrm{Nm})$ equals 29 Hz. It gives the relative difference of frequency about $3 \%$.

After exceed the torque value of $12.5 \mathrm{Nm}$ smaller increments of $\mathrm{F}_{\text {res }}$ are observed. For example, between the screws torque of 12.5 and $15 \mathrm{Nm}$ the $\mathrm{F}_{\text {res }}$ grows at about $8 \mathrm{~Hz}$ (from $912 \mathrm{~Hz}$ to $920 \mathrm{~Hz}$ ). After increase of the torque from 15 to $17 \mathrm{Nm}$ the $\mathrm{F}_{\text {res }}$ increment equals $3 \mathrm{~Hz}$ only. It means that after exceed of the screw torque value of $15 \mathrm{Nm}$ the stabilization of the resonant frequency is observed.

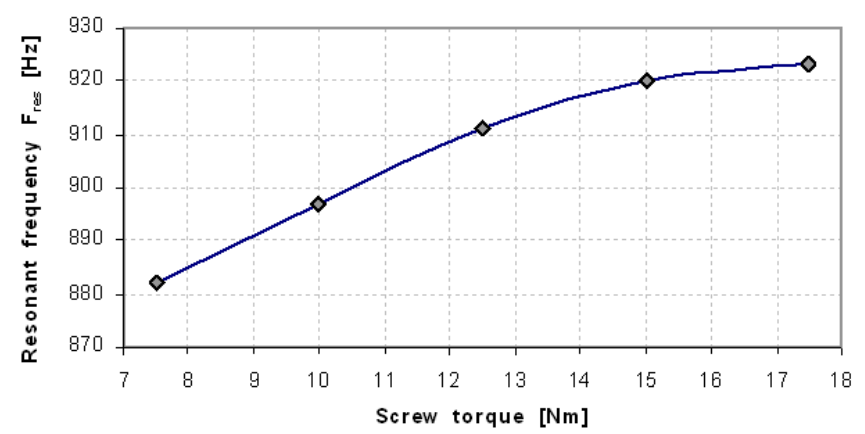

Fig. 9. Resonant frequency as a function of screw torque

\section{Conclusions}

In this work the results of an experimental modal analysis of the turbine blade were presented. The investigations were made using an electrodynamic vibration system. The modal analysis of the blade was divided into two parts. In the first, the amplitude-frequency characteristic of the blade was obtained 
for the frequency range of $400-3600 \mathrm{~Hz}$. As results the resonant frequencies for the first, second and third mode were obtained. In the second part of the study the frequency was limited to the range of $800-1000 \mathrm{~Hz}$, in order to investigate the preliminary settings of the vibration system on results of the modal test. The attention in the second part of the work on the first mode of the resonant vibrations was focused. As a result of presented investigations the following conclusions were formulated:

1. The value of resonant frequency (mode I) of the turbine blade strongly depends on the stiffness of the fixation. In presented investigations the blade fir tree root was compressed with the use of the screw. The difference of resonant frequency between screw torque of $7.5 \mathrm{Nm}$ and $17 \mathrm{Nm}$ equals about $40 \mathrm{~Hz}$. It means that in the experimental modal analysis there is the need for strong fixation of the blade to the shaker head.

2. The $\mathrm{F}_{\text {res }}$ of the blade strongly depends on the intensity of excitation. For excitation of $1 \mathrm{~g}$ the highest value of resonant frequency was observed $(921.4 \mathrm{~Hz})$. After an increase of the intensity to the value of $25 \mathrm{~g}$ the measured $\mathrm{F}_{\text {res }}$ equals $912.6 \mathrm{~Hz}$.

3. The results of performed investigations showed that the sweep rate has a small influence on the resonant frequency (for mode I) of the blade which has a small mass (about 40 grams). The difference of $F_{\text {res }}$ values (between the speed rate of $0.5 \mathrm{~Hz} / \mathrm{s}$ and $64 \mathrm{~Hz} / \mathrm{s}$ ) equals only about $1.4 \mathrm{~Hz}$.

\section{Acknowledgement}

The research leading to these results has received funding from the People Programme (Marie Curie International Research Staff Exchange) of the European Union's Seventh Framework Programme FP7/2007-2013/ under REA grant: PIRSES-GA-2013610547.

\section{References}

[1] Song K.S., Kim S.G., Jung D., Hwang Y.H.: Analysis of the fracture of a turbine blade on a turbojet engine, Eng. Failure Analysis, Vol. 14 (2007) 877-883.

[2] Witek L.: Fatigue investigations of the compressor blades with mechanical defects, Key Engineering Materials, 598 (2014) 269-274.

[3] Maktouf, W., Sai, K.: An investigation of premature fatigue failures of gas turbine blade, Eng. Failure Analysis, 47, (2015) 89-101.

[4] Park M., Hwang Young H., Choi Y.S, Kim T.G.: Analysis of a J69-T-25 engine turbine blade fracture, Eng. Failure Analysis, 9 (2002) 593-601.

[5] Poursaeidi E., Hosein B. Fatigue crack growth simulation in a first stage of compressor blade, Eng. Failure Analysis, 45 (2014) 314-325.

[6] Song K.S., Kim S.G., Jung D., Hwang Y.H. Analysis of the fracture of a turbine blade on a turbojet engine, Eng. Failure Analysis, 14 (2007) 877-83. 
[7] Kermanpur A., Sepehri A.H., Ziaei-Rad S., Nourbakhshnia N., Mosaddeghfar M.: Failure analysis of Ti6Al4V gas turbine compressor blades, Eng. Failure Analysis, 5 (2008) 1052-1064.

\section{EKSPERYMENTALNA ANALIZA MODALNA LOPATKI TURBINY}

\section{Streszczenie}

Praca przedstawia wyniki eksperymentalnej analizy modalnej łopatki turbiny silnika lotniczego. Badania przeprowadzono za pomocą systemu wibracyjnego. Jako wyniki przedstawiono analizę modalną i częstotliwości rezonansowych łopatki turbiny. Uzyskane rezultaty badań eksperymentalnych są zależne od wielu czynników definiowanych na wstępie testu. W pierwszej części pracy określono wpływ prędkości przemiatania oraz intensywności wymuszenia na wartość częstotliwości rezonansowej łopatki turbiny. W następnej części pracy badano wpływ intensywności wymuszenia na wartość amplitudy wibracji łopatki. Jednym z istotnych parametrów mających wpływ na częstotliwości rezonansowe uzyskane w badaniach doświadczalnych jest sztywność uchwytu służącego do zamocowania łopatki do głowicy wzbudnika. Połączenie jodełkowe łopatki zostało utwierdzone przez docisk realizowany za pomocą śruby z gwintem drobnozwojnym, zapewniającym uzyskanie dużych sił docisku przy ograniczonej wartości momentu dokręcenia. W ostatniej pracy określono także wpływ momentu dokręcenia śruby dociskowej na wartości uzyskanych częstotliwości rezonansowych łopatki. Na podstawie przeprowadzonych badań sformułowano wnioski końcowe.

Słowa kluczowe: łopatka turbiny, drgania rezonansowe, badania eksperymentalne, tempo przemiatania, intensywność wymuszenia

DOI: $10.7862 / \mathrm{rm} .2016 .30$

Otrzymano/received: 15.11.2016 r.

Zaakceptowano/accepted: 19.12.2016 r. 